Mijić, A., Liović, I., Sudarić, A., Gadžo, D., Duvnjak, T., Markulj Kulundžić, A., Jovović, Z., Jankulovska, M. (2020): Preliminary results of the influence of sowing dates on the most important sunflower agronomic traits. Agriculture and Forestry, 66 (1): 233-240.

DOI: 10.17707/AgricultForest.66.1.21

\author{
Anto MIJIĆ, Ivica LIOVIĆ, Aleksandra SUDARIĆ ${ }^{1}$, Drena GADŽO', \\ Tomislav DUVNJAK ${ }^{1}$, Antonela MARKULJ KULUNDŽIĆ \\ Zoran JOVOVIĆ ${ }^{3}$, Mirjana JANKULOVSKA ${ }^{4}$
}

\title{
PRELIMINARY RESULTS OF THE INFLUENCE OF SOWING DATES ON THE MOST IMPORTANT SUNFLOWER AGRONOMIC TRAITS
}

\section{SUMMARY}

Timely, well-made sowing is one of the essential prerequisites for successful sunflower production. In order to determine the influence of the sowing date on the most important agronomic sunflower traits, an experiment was conducted according to a random block design at the Osijek location. The experimental material included 22 hybrids of the Agricultural Institute Osijek and three introduced foreign hybrids. Sowing was performed on two dates $\left(21^{\text {st }}\right.$ April and $13^{\text {th }}$ May 2015). The following traits were analyzed: plant height, head diameter, grain yield, oil content, and oil yield. Significantly higher values were found for the plant height and head diameter in the second sowing date and the oil content in the first sowing date. Grain and oil yields were higher but not statistically significant at the second sowing date. The Experimental hybrid OS$\mathrm{H}-10$ had the highest yield of grain $\left(6.970 \mathrm{t} \mathrm{ha}^{-1}\right)$ and oil $\left(3.448 \mathrm{t} \mathrm{ha}^{-1}\right)$, while the experimental hybrid OS-H-4-2 had the highest oil content (55.61\%). yield.

Keywords: sunflower, sowing date, hybrid, grain yield, oil content, oil

\section{INTRODUCTION}

Sunflower (Helianthus annuus L.) is primarily grown because of the oil used in human consumption, but also as a raw material for the processing industry, animal feed, and beekeeping. In the year 2015 there are about 25.5 million hectares in the world, of which around $16.5 \%$ in the European Union. Sunflower is the most important oilseed crop in Croatia. In the period 2000-2014,

\footnotetext{
${ }^{1}$ Corresponding author (anto.mijic@poljinos.hr), Agricultural Institute Osijek, Južno predgrađe 17, 31000, Osijek, CROATIA.

${ }^{2}$ University of Sarajevo, Faculty of Agriculture and Food Sciences, Zmaja od Bosne 8, 71000, Sarajevo, BOSNIA AND HERZEGOVINA.

${ }^{3}$ University of Montenegro, Biotehnical faculty, Mihaila Lalića 1, 81000, Podgorica, MONTENEGRO.

${ }^{4}$ St. Cyril and Methodius University in Skopje, Faculty for Agricultural Sciences and Food, blvd. Aleksandar Makedonski BB 1000 Skopje, MACEDONIA.

Notes: The authors declare that they have no conflicts of interest. Authorship Form signed online. 
areas under sunflower ranged from 20615 to 49769 ha, with grain yields from 1.57 to $3.20 \mathrm{t} \mathrm{ha}^{-1}$ (FAO, 2020).

The priority task in the production of any crop, including sunflower, is to achieve optimal values of the most important agronomic traits. These are mainly quantitative traits, implying that their expression is determined by genetic and environmental factors, as well as their interaction. Environmental factors, which are extremely important in sunflower production, are highlighted by many authors (Miklič et al., 2007; Gadžo et al., 2011; Škorić, 2012). The yield per unit area is the result of the action of factors of variety in interaction with environmental factors (Živanović et al., 2017; Maksimović et al., 2018; Dončić et al., 2019; Rajičić et al., 2019; Rakaščan et al., 2019).

Of many environmental factors, priority should be given to weather, soil and agrotechnical measures applied. The agrotechnical task is to enable the optimal growth and development of cultivated plants, with achieving maximum yield in the quantity and quality of invested labor and resources (Vratarić, 2004). Agrotechnical measures help the plants to adapt by reducing the impact of unfavorable conditions (abiotic and biotic stresses) on the most important agronomic traits.

When applying a semi-intensive technology, the impact of environmental factors (weather and soil) on the quantity of sunflower yield can be reduced substantially (Sárvári, 2010). Considering the occurrence of increasingly dry vegetation seasons, especially in the summer, with less precipitation, higher temperatures, extremely high daily maximums, but also fluctuations in weather parameters over a short period (daily, weekly) (Mijić et al., 2017; Jug et al., 2018), determination of the most favorable sowing date is a very important part of the application of quality agrotechnical measures (Balalić et al., 2007). Therefore, this study aimed to determine the effect of sowing date on the most important agronomic traits of sunflower: plant height, head diameter, grain yield, oil content and oil yield of 25 sunflower hybrids at the Osijek location during 2015 and to identify the best hybrid combinations for further breeding work.

\section{MATERIAL AND METHODS}

The study included 22 new sunflower hybrid combinations of the Agricultural Institute Osijek and three introduced hybrids (standard 1-3) that occupied significant harvesting areas under sunflower in the Republic of Croatia. The sowing was done on two dates $\left(21^{\text {st }}\right.$ April and $13^{\text {th }}$ May 2015) in the experimental field of the Agricultural Institute Osijek in a randomized complete block design with three replicates for each sowing date. Other elements of the experiment were: length of the basic plot $5 \mathrm{~m}$, width $2.8 \mathrm{~m}$, number of plants on the basic plot 88, the spacing between rows $70 \mathrm{~cm}$, row spacing $23 \mathrm{~cm}$, the spacing between blocks $1.5 \mathrm{~m}$.

Standard agrotechnique for sunflower production was applied. In the fall, basic fertilization was carried out with $300 \mathrm{~kg} \mathrm{ha}^{-1}$ of NPK fertilizer (7:20:30) and $50 \mathrm{~kg} \mathrm{ha}^{-1}$ of UREA (carbamide, $46 \% \mathrm{~N}$ ). Prior to sowing, $200 \mathrm{~kg} \mathrm{ha}^{-1} \mathrm{NPK}$ 
(7:20:30) was applied with and furrow closing. The sowing was done by hand. In phase four of the permanent leaf pairs (Schneiter and Miller, 1981), $100 \mathrm{~kg} \mathrm{ha}^{-1}$ of KAN (calcium ammonium nitrate, $27 \% \mathrm{~N}$ ) was applied. Weed protection was performed after sowing, and before emergence with a combination of herbicides metolachlor + fluchloridone + oxyfluorfen $\left(1+1.5+0.5 \mathrm{l} \mathrm{ha}^{-1}\right)$. Boscalid + dimoxystrobin $\left(0.5 \mathrm{l} \mathrm{ha}^{-1}\right)$ in the butonization phase was used for disease control. The harvest was done with a plot combine harvester.

The most important agronomic traits of sunflower were analyzed. Plant height and head diameter were measured at the physiological maturity stage. The grain yield from the plot was calculated per hectare according to the standard ( $9 \%$ moisture and $2 \%$ impurity). The oil content was determined by a magnetic resonance analyzer (MQA 7005 NMR Analyzer), and the oil yield was calculated based on grain yield and oil content. The obtained values of the analyzed traits were systematized by hybrids and sowing dates for statistical processing by analysis of variance (ANOVA), and mean values were compared by the LSD test (SAS, 2003).

\section{Weather conditions and soil traits}

According to the data presented in Table 1, the year 2015 was dry. Specifically, the precipitation deficit in the observed period in 2015 (I-IX month) was by $21 \%$ less $(110.9 \mathrm{~mm})$ and in vegetation period by $38 \%$ less $(151.6 \mathrm{~mm})$ respectively, compared to the long-term average (2000-2014). Particularly pronounced lack of rainfall was observed in April, June, July and September, that is, during most of the vegetation period.

Temperatures in each month were higher than the long-term average, except April. The highest temperatures were noted in July and August. The trend of increasingly dry years, with precipitation deficits and elevated temperatures, was evident in 2015.

Table 1 . Monthly precipitation $(\mathrm{mm})$, the average monthly temperature $\left({ }^{\circ} \mathrm{C}\right)$, and their long-term average (2000-2014)

\begin{tabular}{|c|r|r|c|c|}
\hline \multirow{2}{*}{ Month } & \multicolumn{2}{|c|}{ Precipitation $(\mathrm{mm})$} & \multicolumn{2}{c|}{ Temperature $\left({ }^{\circ} \mathrm{C}\right)$} \\
\cline { 2 - 5 } & 2015 & $2000-2014$ & 2015 & $2000-2014$ \\
\hline I-III & 167.9 & 127.2 & - & - \\
\hline IV & 10.6 & 52.4 & 12.4 & 12.6 \\
\hline V & 108.6 & 78.2 & 17.9 & 17.4 \\
\hline VI & 44.9 & 85.1 & 21.3 & 20.8 \\
\hline VII & 7.6 & 56.9 & 24.9 & 22.5 \\
\hline VIII & 50.8 & 65.0 & 24.1 & 22.0 \\
\hline IX & 29.1 & 65.6 & 19.0 & 16.7 \\
\hline Amount (I-IX) & 419.5 & 530.4 & - & - \\
\hline Amount (IV-IX) & 251.6 & 403.2 & - & - \\
\hline Average (IV-IX) & - & - & 19.9 & 18.7 \\
\hline
\end{tabular}

Source: Croatian Meteorological and Hydrological Service 
The type of soil was an eutric cambisol, clayey loam texture with neutral reaction ( $\mathrm{pH}$ in $\mathrm{KCl}$ 6.61). The humus content in the soil was 2.26, which classifies it in low humus soils, but is well supplied with phosphorus (36.90 $\mathrm{mg} / 100 \mathrm{~g}$ soil) and potassium (29.43 mg/100 g soil).

\section{RESULTS AND DISCUSSION}

The sowing date had a significant effect on plant height, head diameter, and oil content (Table 2). Studied hybrids differed significantly for all traits, and the interaction of sowing date and hybrids was significant only for oil content.

Large variations in plant height within the sowing dates were found between the hybrids, indicating divergence of the material selected for the study (Table 3). It is also clearly evident that the plants in the second sowing date were, on average, statistically significantly higher than the plants in the first sowing date (214 cm versus $202 \mathrm{~cm}$ ), which is in agreement with the studies of Liović et al. (2015). Different results were obtained by Krizmanić et al. (2001) and Vratarić (2004). Higher plant height values in the second sowing date may be related, among other factors, to above-average rainfall during May $(108.6 \mathrm{~mm})$, which greatly influenced the expression of this trait.

\section{Table 2. Analysis of variance}

\begin{tabular}{|c|c|c|c|c|c|}
\hline \multirow{2}{*}{$\begin{array}{c}\text { Source of } \\
\text { variation }\end{array}$} & \multicolumn{5}{|c|}{ Mean square } \\
\cline { 2 - 6 } & $\begin{array}{c}\text { Plant } \\
\text { height }\end{array}$ & $\begin{array}{c}\text { Head } \\
\text { diameter }\end{array}$ & $\begin{array}{c}\text { Grain } \\
\text { yield }\end{array}$ & Oil content & Oil yield \\
\hline Sowing date & $5162.7^{* *}$ & $29.9^{* *}$ & $0.963^{\text {n.s. }}$ & $15.34^{* *}$ & $0.057^{\text {n.s. }}$ \\
\hline Hybrid & $2225.3^{* *}$ & $23.9^{* *}$ & $3.773^{* *}$ & $53.69^{* *}$ & $0.868^{* *}$ \\
\hline $\begin{array}{c}\text { Sowing date } \mathrm{x} \\
\text { Hybrid }\end{array}$ & $68.0^{\text {n.s. }}$ & $3.02^{\text {n.s. }}$ & $0.416^{\text {n.s. }}$ & $2.00^{* *}$ & $0.069^{\text {n.s }}$ \\
\hline
\end{tabular}

${ }^{n s} \mathrm{~F}$ - test not significant; ${ }^{* *} \mathrm{~F}$ - test significant on level $\mathrm{P}<0.01$

In the first sowing date, the average head diameter was $21.2 \mathrm{~cm}$ and was statistically significantly lower than the second sowing date $(22.1 \mathrm{~cm})$. Variations were expressed for individual hybrids so that the head diameter values ranged from 18.7 to $27.7 \mathrm{~cm}$ in the first sowing date, while in the second date, these variations were even more emphasized $(19.3-32.3 \mathrm{~cm})$. The head diameter is of great importance for successful sunflower production and depends on the sowing date (Ahmed et al., 2015). Balalić et al. (2016) point out that head diameter affects the number of flowers and grains per head, which directly affects the grain yield per plant. According to Škorić (2012), the head diameter in sunflower hybrids is generally 20 to $30 \mathrm{~cm}$. Unlike the plant height and head diameter, where the values were higher in the second sowing date, the oil content was statistically significantly higher in the first sowing date (Table 4), with large variations in both sowing dates (first term: 43.71-55.20 \%; second term: 41.82$56.38 \%$ ). Oil content is a complex trait determined by genetic and environmental factors and is an important component of oil yield (Leon et al., 2003, Balalić et 
al., 2012). Krizmanić et al. (2012; 2013) indicate that the oil content is greatly influenced by temperature and air humidity, by environmental factors, as well as soil type, and the application of agrotechnical measures.

Table 3. Variations in traits' values and averages by sowing date for plant height and head diameter

\begin{tabular}{|c|c|c|c|c|}
\hline \multirow{2}{*}{ Sowing date } & \multicolumn{2}{|c|}{$\begin{array}{c}\text { Plant height } \\
(\mathrm{cm})\end{array}$} & \multicolumn{2}{c|}{$\begin{array}{c}\text { Head diameter } \\
(\mathrm{cm})\end{array}$} \\
\cline { 2 - 5 } & Average & Variation & Average & Variation \\
\hline I & 202 & $168-237$ & 21.2 & $18.7-27.7$ \\
\hline II & 214 & $180-249$ & 22.1 & $19.3-32.3$ \\
\hline Average & 208 & & 21.6 & \\
\hline LSD 5\% & 2.8 & & 0.6 & \\
\hline
\end{tabular}

Large variations in grain and oil yields between individual hybrids have been identified within the sowing date. Although there were no statistically significant differences between sowing dates for grain and oil yields, it should be noted that they were larger in the second sowing date. Most authors (Krizmanić et al., 2001; Crnobarac et al., 1996; Crnobarac and Dušanić, 2000; Vratarić, 2004; Liović et al., 2015) concluded that delayed sowing in similar agro-ecological conditions leads to a decrease in grain and oil yields.

Table 4. Variations in traits' values and averages by sowing date for grain yield, oil content and oil yield

\begin{tabular}{|c|c|c|c|c|c|c|}
\hline \multirow{2}{*}{$\begin{array}{c}\text { Sowing } \\
\text { date }\end{array}$} & \multicolumn{2}{|c|}{$\begin{array}{c}\text { Grain yield } \\
\left(\mathrm{t} \mathrm{ha}^{-1}\right)\end{array}$} & \multicolumn{2}{c|}{$\begin{array}{c}\text { Oil content } \\
\text { (\% in D.M. }\end{array}$} & \multicolumn{2}{|c|}{$\begin{array}{c}\text { Oil yield } \\
\left(\mathrm{t} \mathrm{ha}^{-1}\right)\end{array}$} \\
\cline { 2 - 8 } & Average & Variation & Average & Variation & Average & Variation \\
\hline I & 5.689 & $2.899-6.780$ & 51.37 & $43.71-55.20$ & 2.655 & $1.418-3.404$ \\
\hline II & 5.849 & $3.089-7.161$ & 50.73 & $41.82-56.38$ & 2.694 & $1.475-3.492$ \\
\hline Average & 5.769 & & 51.05 & & 2.675 & \\
\hline $\begin{array}{c}\text { LSD } \\
\text { 5\% }\end{array}$ & $\mathrm{ns}$ & & 0.31 & & $\mathrm{~ns}$ & \\
\hline
\end{tabular}

Table 5 shows the average values of the first and second sowing date for the analyzed traits. After the LSD test, the investigated hybrids were ranked. The plant height was ranked in 13 ranks (a-m), head diameter 7 (a-g), grain yield 10 (a-j), oil content 14 (a-n), and oil yield 12 (a-l). This way of presenting data provides insight into the statistical justification of differences between individual hybrids; respectively, there are no statistically significant differences between the hybrids marked with the same letter. By grain and oil yields, as the most important agronomic characteristics, highlighted several experimental hybrids. 
Table 5. Average traits value for both sowing dates

\begin{tabular}{|c|c|c|c|c|c|}
\hline Hybrid & $\begin{array}{l}\text { Plant } \\
\text { height } \\
(\mathrm{cm})\end{array}$ & $\begin{array}{l}\text { Head } \\
\text { diameter } \\
(\mathrm{cm})\end{array}$ & $\begin{array}{l}\text { Grain yield } \\
\qquad\left(\mathrm{t} \mathrm{ha}^{-1}\right)\end{array}$ & $\begin{array}{c}\text { Oil } \\
\text { content } \\
\text { (\% in } \\
\text { D.M.) }\end{array}$ & $\begin{array}{c}\text { Oil yield } \\
\left(\mathrm{t} \mathrm{ha}^{-1}\right)\end{array}$ \\
\hline OS-H-10 & $239^{\mathrm{ab}}$ & $22.3^{b c}$ & $6.970^{\mathrm{a}}$ & $54.39^{\text {bc }}$ & $3.448^{\mathrm{a}}$ \\
\hline OS-H-20 & $222^{\text {cde }}$ & $21.2^{\text {bcdefg }}$ & $6.634^{\mathrm{ab}}$ & $50.40^{j}$ & $3.042^{b}$ \\
\hline OS-H-120 & $219^{\text {def }}$ & $21.8^{\text {bcde }}$ & 6.259 bcde & $52.73^{\text {ef }}$ & $3.001^{b}$ \\
\hline OS-H-163 & $209^{\text {ghijk }}$ & $21.8^{\text {bcde }}$ & $6.104^{\text {bcdef }}$ & $53.82^{\mathrm{cd}}$ & $2.988^{\mathrm{bc}}$ \\
\hline OS-H-28 & $226^{\mathrm{cd}}$ & $21.3^{\text {bcdef }}$ & $5.949^{\text {bcdefgh }}$ & $55.15^{\mathrm{ab}}$ & $2.986^{\mathrm{bc}}$ \\
\hline OS-H-30 & $216^{\text {defgh }}$ & $22.0^{\mathrm{bcd}}$ & $6.188^{\text {bcde }}$ & $52.24^{\text {efg }}$ & $2.942^{\text {bcd }}$ \\
\hline STANDARD 1 & $185^{1}$ & $22.3^{b c}$ & 6.268 bcde & $50.43^{j}$ & 2.879 bcde \\
\hline OS-H-16 & $201^{k}$ & $21.0^{\text {cdefg }}$ & $6.191^{\text {bcde }}$ & $50.75^{\text {hij }}$ & $2.858^{\text {bcdef }}$ \\
\hline OS-H-2 & $214^{\text {efghi }}$ & $20.3^{\text {cdefg }}$ & $6.182^{\text {bcde }}$ & $50.67^{\mathrm{ij}}$ & $2.848^{\text {bcdef }}$ \\
\hline OS-H-103 & $207^{\text {hijk }}$ & $21.8^{\text {bcde }}$ & $5.670^{\text {efgh }}$ & $55.10^{a b}$ & $2.844^{\text {bcdef }}$ \\
\hline OS-H-36 & $230^{\mathrm{bc}}$ & $22.2^{\text {bcd }}$ & $6.027^{\text {bcdef }}$ & $51.76^{\text {fgh }}$ & $2.834^{\text {bcdef }}$ \\
\hline OS-H-5 & $218^{\text {defg }}$ & $21.2^{\text {bcdefg }}$ & $6.378^{a b c d}$ & $47.75^{\mathrm{lm}}$ & $2.766^{\text {bcdefg }}$ \\
\hline OS-H-4-2 & $205^{\mathrm{ijk}}$ & $20.3^{\text {cdefg }}$ & $5.438^{\text {fghi }}$ & $55.61^{a}$ & $2.753^{\text {bcdefg }}$ \\
\hline OS-H-4 & $203^{\mathrm{kj}}$ & $20.2^{\text {defg }}$ & $5.961^{\text {bcdefg }}$ & $49.22^{k}$ & $2.671^{\text {cdefgh }}$ \\
\hline OS-H-29E & $226^{\mathrm{cd}}$ & $20.7^{\text {cdefg }}$ & $5.655^{\text {efgh }}$ & $51.46^{\text {ghij }}$ & $2.650^{\text {defghi }}$ \\
\hline OS-H-42 & $211^{\text {fghij }}$ & $19.8^{\text {efg }}$ & $5.589^{\text {efgh }}$ & $51.38^{\text {ghij }}$ & $2.618^{\text {efghij }}$ \\
\hline OS-H-21 & $243^{a}$ & $23.2^{b}$ & $5.875^{\text {cdefgh }}$ & $48.34^{\mathrm{kl}}$ & $2.577^{\text {efghij }}$ \\
\hline OS-H-22/67 & $231^{b c}$ & $21.2^{\text {bcdefg }}$ & $6.548^{a b c}$ & $42.77^{n}$ & $2.545^{\text {fghij }}$ \\
\hline OS-H-50 & $205^{\mathrm{ijk}}$ & $22.3^{b c}$ & $5.827^{\text {defgh }}$ & $47.28^{\mathrm{lm}}$ & $2.501^{\text {ghijk }}$ \\
\hline OS-H-22 & $187^{1}$ & $19.7^{\mathrm{fg}}$ & $5.265^{\text {hi }}$ & $51.66^{\text {fghi }}$ & $2.473^{\text {ghijk }}$ \\
\hline STANDARD 2 & $189^{1}$ & $22.0^{\text {bcd }}$ & $5.491^{\text {fghi }}$ & $47.16^{\mathrm{m}}$ & $2.358^{\text {hijk }}$ \\
\hline STANDARD 3 & $182^{\mathrm{lm}}$ & $19.2^{\mathrm{g}}$ & $5.319^{\text {ghi }}$ & $48.27^{\mathrm{kl}}$ & $2.335^{\mathrm{ijk}}$ \\
\hline OS-H-44 & $174^{\mathrm{m}}$ & $21.0^{\text {cdefg }}$ & $4.866^{\mathrm{ij}}$ & $52.29^{\mathrm{efg}}$ & $2.315^{\mathrm{jk}}$ \\
\hline OS-H-49 & $184^{\operatorname{lm}}$ & $21.3^{\text {bcdef }}$ & $4.571^{\mathrm{j}}$ & $52.59^{\mathrm{ef}}$ & $2.188^{\mathrm{k}}$ \\
\hline OS-H-46-7 & $181^{\mathrm{lm}}$ & $30.0^{\mathrm{a}}$ & $2.994^{\mathrm{k}}$ & $53.14^{\text {de }}$ & $1.446^{1}$ \\
\hline Average & 207 & 21.6 & 5.769 & 51.05 & 2.675 \\
\hline LSD 5\% & 10 & 2.0 & 0.686 & 1.08 & 0.317 \\
\hline Min & 174 & 19.2 & 2.994 & 42.77 & 1.446 \\
\hline Max & 243 & 30.0 & 6.970 & 55.61 & 3.448 \\
\hline
\end{tabular}




\section{CONCLUSIONS}

Based on the analyzed data for plant height, head diameter, grain yield, oil content, and oil yield of sunflower hybrids in two sowing dates, the following conclusions are:

1. The sowing date had a significant impact on plant height, head diameter, and oil content.

2. Statistically significant differences were found between the hybrids for all analyzed traits.

3. The interaction of the sowing date and hybrid was only significant for the oil content.

4. In the second sowing date, higher values were determined for all analyzed traits except for oil content.

5. Several experimental hybrids have been distinguished by grain and oil yield and oil content and can be considered as promising hybrids for further research.

\section{REFERENCES}

Ahmed B, Sultana M, Zaman J, Paul SK, Rahman MM, Islam MR, Majumdar F. 2015. Effect of sowing date on the yield of sunflower. Bangladesh Agron. J. 18, 1: 1-5.

Balalić I, Crnobarac J, Dušanić N. 2007. Planting date effects on oil yield in sunflower (Helianthus annuus L.). Helia. 30, 47: 153-158.

Balalić I, Zorić M, Branković G, Terzić S, Crnobarac J. 2012. Interpretation of hybrid x sowing date interaction for oil content and oil yield in sunflower. Field Crops Research. 137: 70-77.

Balalić I, Crnobarac J, Jocić S, Miklič V, Radić V, Dušanić N. 2016. Variability of head diameter in sunflower hybrids depending of planting date. Genetika. 48, 3: 983990.

Crnobarac J, Dušanić N, Ćupina, T. 1996. Mogućnosti povećanja i stabilizacije prinosa kod suncokreta. Zbornik radova Instituta za ratarstvo i povrtarstvo, Novi Sad. 26. 47-66.

Crnobarac J., Dušanić N. 2000. Utjecaj pojedinih agrotehničkih mera na prinos suncokreta u 1999. godini. Zbornik referata 34. Seminara agronoma 2000, Naučni institut za ratarstvo i povrtarstvo. Novi Sad. 89-103.

Dončić D., Popović V. M., Lakić Ž., Popović D. B., Petković Z. 2019. Economic analysis of wheat production and applied marketing management. Agriculture and Forestry. 65, 4: 91-100.

FAO (2020): FAOSTAT Database 2020. http://faostat.fao.org/site/567/DesktopDefault.aspx?PageID=567\#ancor

Gadžo D, Đikić M., Mijić, A. 2011. Industrijsko bilje. Poljoprivredno- prehrambeni fakultet Sarajevo.

Jug D, Jug I, Brozović B, Vukadinović V, Stipešević B, Đurđević B. 2018. The role of conservation agriculture in mitigation and adaptation to climate change. Poljoprivreda. 24, 1: 35-44.

Krizmanić M, Mijić A, Bilandžić M, Duvnjak T, Jurković Z, Sudar R. 2001. Utjecaj agrotehnike, roka sjetve i sortimenta na uzgoj suncokreta u aridnim uvjetima. Sjemenarstvo. 18, 1-2: 43-55. 
Krizmanić M, Liović I, Mijić A, Krizmanić G, Šimić B, Duvnjak T, Bilandžić M, Marinković R, Gadžo D, Markulj, A. 2012. Utjecaj okolina na kvantitativna svojstva novih OS-hibrida suncokreta. Sjemenarstvo. 29, 3-4: 121-135.

Krizmanić M, Mijić A, Liović I, Sudarić A, Sudar R, Duvnjak T, Krizmanić G, Bilandžić M 2013. Utjecaj okoline na sadržaj ulja i sastav masnih kiselina kod novih OShibridnih kombinacija suncokreta. Poljoprivreda. 19, 1: 41-47.

Leon AJ, Andrade FH, Lee M. 2003. Genetic analysis of Seed Oil Concentration across Generations and Environments in Sunflower. Crop Science. 43,1: 135-140.

Liović I, Mijić A, Markulj A. 2015. Utjecaj roka sjetve na proizvodna svojstva hibrida suncokreta. Zbornik sažetaka 50. hrvatskog i 10. međunarodnog simpozija agronoma. 171-172.

Maksimović L., Popović V., Stevanović P. 2018. Water and irrigation requirements of field crops grown in central Vojvodina, Serbia. Agriculture and Forestry. 64, 1: 133-144.

Miklič V, Škorić D, Balalić I, Jocić S, Jovanović D, Hladni N, Marinković R, Joksimović J, Gvozdenović S. 2007. Rezultati ispitivanja NS hibrida suncokreta u ogledima i preporuka za setvu u 2007. godini. Zbornik radova Instituta za ratarstvo i povrtarstvo, Novi Sad. 43, 1: 115-128.

Mijić A, Liović I, Sudarić A, Gadžo D, Jovović Z, Jankulovska M, Markulj Kulundžić A, Duvnjak T. 2017. The effect of environment on the phenotypic expression of grain yield, oil content and oil yield in sunflower hybrids. Agriculture and Forestry. 63, 1: 309-318.

Rajičić V., Milivojević J., Popović V., Branković S., Đurić N., Perišić V., Terzić D. 2019. Winter wheat yield and quality depending on the level of nitrogen, phosphorus and potassium fertilization. Agriculture and Forestry. 65, 2: 79-88.

Rakaščan N., Dražić, G., Živanović Lj., Ikanović J., Jovović Z., Lončar M., Bojović R., Popović V. 2019. Effect of genotypes and locations on wheat yield components. Agriculture and Forestry, 65, 1: 233-242.

SAS. 2003. SAS for Windows (r) 9.1. SAS Institute Inc., Cary, NC, USA.

Sarvari M. 2010. Sustainable, environmental friendly field crops production in changing climate conditions. In Molnárová J. and Pepó, P. (Eds.). Sustainable, environmental friendly maize production in changing climate conditions (monograph). Slovak University of Agriculture of Nitra. 191.

Schneiter A, Miller JF. 1981. Description of Sunflower Growth Stages. Crop Science, 21: 901-903.

Škorić D. 2012. Sunflower breeding. In Sunflower Genetics and Breeding. D. Škorić, Z. Sakač (ed.), International Monography. 165-354.

Vratarić M. 2004. Agrotehnika suncokreta. U Suncokret Helianthus annuus L. Vratarić (ur.). Poljoprivredni institut Osijek. Hrvatska. 187-216.

Živanović Lj., Savić J., Kolarić Lj., Ikanović J., Popović V., Novaković M. 2017. The influence of genotype on wheat, soybean, corn and sunflower grain yield. Journal of Institute of PKB Agroekonomik, Belgrade. 23, 1-2: 39-48. 